\title{
Trade Policy in the Asia Pacific after Trans-Pacific Partnership
}

\author{
Barbara Weisel, Rock Creek Global Advisors, USA
}

Asia-Pacific countries are making progress in developing trade and investment frameworks through various regional approaches. These include the Comprehensive and Progressive Trans-Pacific Partnership (CPTPP), the Regional Comprehensive Economic Partnership (RCEP), the Pacific Alliance, EU trade agreements with Asia-Pacific countries, and China's Belt and Road Initiative. The United States (US) had been heavily invested in a regional approach through the Trans-Pacific Partnership (TPP), but the Trump administration withdrew from that agreement in favor of a bilateral approach, reflecting its America-First policies. This article discusses the economic and foreign policy implications of these different approaches in an era of growing tensions between the US and China.

\section{The Original US Vision for the Trans-Pacific Partnership}

Ten years ago, my colleagues and I at the Office of the US Trade Representative began developing options for US engagement in the Asia Pacific. With its large and fast-growing markets, this region presented enormous opportunities for the US, and we were determined to ensure that U.S. businesses could take advantage of them. We sought to position the US commercially and strategically for the long term.

It was clear that unless the US was a first-mover in setting trade rules, US businesses would become rule-takers. Other countries were negotiating bilateral and regional trade agreements in the Asia Pacific more quickly than the US, putting US businesses at a competitive disadvantage. Many observers concluded that the US needed to replace the slow bilateral approach it had been pursuing with a regional approach that could yield faster results.

It also was clear that a regional approach would promote the development of common trade rules to replace the "spaghetti bowl" of rules that resulted from the various bilateral agreements. This would help US businesses operate more seamlessly across the region and link directly to regional value chains. A new regional agreement also would create the opportunity to expand the rulebook to include next-generation trade and investment rules. Among these would be rules to address behind-the-border barriers, the emergence of digital trade, and distortions caused by state-owned enterprises. In addition, the agreement would have to include strong enforcement mechanisms to ensure the rules were fully implemented.

Of course, developing a new regional trade agreement in the Asia Pacific would have geopolitical implications. This agreement would be an opportunity to further strengthen US leadership, promote the rule of law, deepen US alliances with key partners, build common cause with like-minded countries, and embed the US in regional economic architecture that would reflect its enduring role as a Pacific power.

After detailed consultations over many months, the TPP negotiations were finally launched. Starting with five countries, the TPP negotiations eventually expanded to 12 countries Australia, Brunei Darussalam, Canada, Chile, Japan, Malaysia, Mexico, New Zealand, Peru, Singapore, the US, and Vietnam. With the signing of the agreement in early 2016, the US and its TPP partners were on the cusp on realizing their vision. 


\section{Trade Policy under Trump}

Trade became an important theme in 2016 US presidential campaign, with both Donald Trump and Hillary Clinton opposing TPP. Once elected, Trump made one of his first acts withdrawal from the TPP, to be replaced by bilateral agreements with key countries. The move reflected President Trump's deep conviction that negotiating bilaterally rather than regionally would provide the US greater leverage to achieve his primary objective of eliminating US trade deficits and his visceral opposition to the policies of the previous administration. Unlike Clinton, he did not see the geopolitical advantages of the TPP and did not give consideration to amending it rather than withdrawing.

\section{KORUS and NAFTA Renegotiations}

As a first order of business, Trump announced that he would renegotiate the US trade agreement with Korea (KORUS) and the North America Free Trade Agreement (NAFTA). To build leverage, the Trump administration threatened to withdraw from these agreements and imposed steel and aluminum tariffs on US trading partners (many of which retaliated in kind) under Section 232, a little used provision of the Trade Expansion Act of 1962 that allows the president to impose tariffs or quotas on imports of that are determined to threaten national security. Many viewed the Section 232 action as illegitimate, and several countries initiated World Trade Organization (WTO) dispute settlement cases against this US action.

Korea agreed to trade negotiations, which it hoped would quickly resolve bilateral trade issues and allow it to keep the focus on regional security issues and the North Korean threat. After several months of talks, the two sides agreed to minor amendments to the original KORUS.

The Trump administration then used the threat of withdrawal, the steel and aluminum tariffs, and the threat of Section 232 tariffs on autos and auto parts to pressure Mexico and Canada to accede to its demands. The US-Mexico-Canada Agreement (USMCA) that the three countries concluded on September 30, 2018, draws heavily on TPP, but it also includes new several new elements, which the Trump administration has said it will use as a template for future FTA negotiations. These include provisions aimed at: (a) reducing trade deficits, (b) retaining continued US leverage over its trading partners, and (c) targeting China.

\section{Negotiations with Japan and the EU}

The US is also pursuing trade agreements with Japan and the EU to address what it views as unbalanced trade relationships. In addition to addressing the US bilateral trade deficits with these countries, the US hopes to reduce frictions with them so as to be able to focus its firepower on China and then enlist them as allies in its conflict with China. Having watched the US in the NAFTA renegotiation and being skeptical about the likelihood of a successful conclusion given US objectives, both Japan and the EU initially resisted US overtures. Japan also hoped it could persuade the US to rejoin TPP. However, facing the threat of Section 232 tariffs on autos, Japan and the EU agreed to initiate bilateral talks, while the US agreed not impose 232 tariffs on autos as long as the talks were ongoing. The Trump administration notified Congress in mid-October of its intent to launch negotiations with Japan and the EU (as well as the UK) but dates for starting these talks have not yet been set.

\section{Addressing Concerns on China}

Even as it pursues these trade negotiations, the Trump administration's top trade policy priority is China, which it has identified as the principal commercial and geo-strategic threat facing the US. In August 2017, it launched an investigation of China's trade practices under section 301 of the Trade Act of 1974, which allows the President to take actions to address foreign measures it determines to be unreasonable or discriminatory and that burden or restrict US commerce. In March 2018, the Trump administration produced a detailed report documenting unfair and discriminatory Chinese practices - a list of concerns shared by the US Congress, many foreign governments, and US and foreign businesses. To create leverage on China to force it to reform its economy and trade policies, the Trump administration imposed successive rounds of tariffs on Chinese imports into the US, now totaling $\$ 250$ billion. It also threatened to raise the existing tariffs and impose a final tranche of tariffs covering the remaining $\$ 257$ billion in Chinese imports not already hit with US tariffs. China responded with its own retaliatory tariffs and other non-tariff measures. In early December 2018, Presidents Trump and Xi announced a temporary ceasefire, with the two sides agreeing to refrain from taking further tariff actions until March 1 while they engage in negotiations on a range of issues. Meanwhile, the Trump administration's

\section{As the US has pursued its "America-First" strategy, other countries have continued to pursue their own strategies.}

trade conflict with China has expanded into a comprehensive government-wide strategy to respond to the challenges posed by China, including intellectual property theft, forced technology transfer, and unfair subsidies, as well as human rights, debt diplomacy, election interference, and the militarization of the South China Sea. The Chinese leadership has reacted, including by redoubling its efforts to dominate next-generation 
technologies and calling for greater "self-reliance," as it works to wean itself from dependence on US trade.

\section{Developments on Asia-Pacific Regional Trade Architecture}

As the US has pursued its "America-First" strategy, other countries have continued to pursue their own strategies. Many have focused on developing Asia-Pacific trade frameworks that will increase their market access and deepen their supply chains across the Asia Pacific, promote rules that reflect their interests, and strengthen their regional alliances. These emerging regional frameworks include:

\section{CPTPP}

Following the US withdrawal from TPP, many observers assumed the agreement was dead. However, in a demonstration of their commitment to free trade, a high-standard regional architecture and the preservation of benefits they had negotiated, Japan led the remaining 11 TPP countries to conclude the CPTPP. The new agreement, which entered into force on December 30, 2018, keeps intact the market access commitments negotiated in TPP and almost all of the TPP rules. The CPTPP members will now look to expand membership in the agreement. Several countries already have expressed interest in joining, and with the "plug and play" structure of the agreement, negotiations with new members may proceed relatively quickly.

\section{RCEP}

RCEP was launched in 2012 by the ten countries of the Association of Southeast Asian Nations (ASEAN) - Brunei Darussalam, Cambodia, Indonesia, Laos, Malaysia, Myanmar, Philippines, Singapore, Thailand, and Vietnam - and their existing FTA partners: Australia, China, India, Japan, Korea, and New Zealand. Their goal was to strengthen their economic linkages, promote development, and harmonize and upgrade their existing agreements. The Southeast Asian countries were behind the ASEAN-centric architecture and its incremental approach, which many saw as more appropriate than the more comprehensive, high-standard approach of the TPP. China also supported the RCEP approach as an Asia-only alternative to TPP. The 16 countries have held two dozen rounds of talks, but negotiations have proceeded slowly. They have encountered deep divisions amongst the members, including about the appropriate level of ambition they should seek to achieve. However, the entry into force of the CPTPP has increased the determination of RCEP countries to conclude their agreement. For China, concluding the deal would provide important commercial and geopolitical benefits given its growing trade tensions with the US. The 16 countries are seeking to finalize the agreement in 2019.

\section{Pacific Alliance}

The Pacific Alliance (Alianza del Pacifico) was established in 2011 by Chile, Colombia, Mexico, and Peru to promote regional integration, growth and development, free trade and in- vestment, integrated financial markets, free movement of people, and political dialogue. The Pacific Alliance has attracted more attention as a pathway for integration in Latin America than as a potential Asia-Pacific economic architecture. However, the four Pacific Alliance members see the initiative as a framework for integration across the Asia-Pacific region and beyond. To join the agreement, a new member must have bilateral FTAs with each of the other Pacific Alliance members. The Pacific Alliance encourages associate members, which must commit to negotiate free trade agreements with each Pacific Alliance member. Costa Rica, Panama, and Ecuador are seeking full Pacific Alliance membership, while Canada, Australia, New Zealand, and Singapore are seeking associate membership. In addition, the Pacific Alliance is open to observers, of which there are currently 55 countries from around the world. Asian countries have put a higher priority on their own regional initiatives, but many have joined the Pacific Alliance as observers, including China, India, Indonesia, Korea, Japan, and Thailand, as well as the US.

\section{EU Deals}

The EU has sought to deepen its economic partnerships and promote EU rules in the Asia Pacific primarily through a bilateral approach as an initial step. It has concluded bilateral FTAs with Korea, Japan, Singapore, and Vietnam. It is negotiating an agreement with Indonesia and launched negotiations with Australia, New Zealand, Thailand, Malaysia, and the Philippines (although the EU suspended the latter over human rights concerns). Its agreements focus on opening markets for EU agriculture and certain industrial goods and rules that reflect the EU's unique approach to such issues as standards, intellectual property, investment, digital trade, and labor. In 2015, the EU proposed to work toward an EU-ASEAN regional FTA, building on bilateral agreements between EU and ASEAN member states. Progress toward this agreement is likely to be slow. Still, the EU continues to make strengthening ties with the Asia-Pacific region a priority. It holds regular meetings of the Asia-Europe group, the latest held in October 2018 and attended by heads of state and senior officials of 51 Asian and European countries. The EU also regularly holds summits with China, the latest held in July 2018, during which the two sides agreed to accelerate work on their bilateral investment agreement.

\section{Belt and Road Initiative (BRI)}

China designed the BRI as a means of strengthening its trade and investment links, financial integration, and regional cooperation with countries across East, Central, Southeast, and South Asia, as well as the Middle East, North Africa, Eastern Europe, and Latin America. It is intended to expand China's export markets, provide it with access to foreign resources, and promote the internationalization of the RMB. With the infrastructure needs of the target BRI countries, Chinese transport and digital economy infrastructure, financing, and increased trade have been welcomed, despite concerns about debt sustainability, transparency, and the implications of increasing dependence on 
China. Although the BRI is not being billed as an alternative regional trade architecture, it is providing China the means to achieve market access, establish regional supply chains, set trade and investment rules and standards, and promote new economic and governance models across the Asia Pacific.

\section{Outlook}

Looking ahead, Asia-Pacific countries will continue to make progress in establishing the architecture that will govern trade and investment in the region in the future. With CPTPP now in force and new members already interested in joining, it will play a prominent role in the design of regional rules and trade flows.

However, other initiatives will also be influential. China's continued expansion of the BRI will increase access to regional markets, allow it to set trade and investment rules, and extend its influence. The EU trade agreements with Japan, Singapore, and likely Vietnam will enter into force in 2019 and it will make progress in negotiations with other countries, providing it access to regional markets and allowing it to set trade rules on key issues. If concluded, RCEP will be important in strengthening supply chains across the Indo-Pacific, and the expansion of the Pacific Alliance will strengthen linkages between the Americas and Asia.

Meanwhile, the Trump administration will continue to pursue its bilateral approach. Although it may conclude a bilateral goods agreement with Japan, it is likely to reach few, if any, other trade agreements with regional partners in the next few years. It also will continue to press companies to relocate production to the US and to reduce their reliance on foreign supply chains, including through policies designed to decouple the US and Chinese economies.

Regional supply chains will continue to expand, but increasingly without US links. Companies may produce in the US market for sales in the US, but US policies will discourage them from using the US as an export base. To avoid US tariffs on inputs, connect to supply chains, and gain the same preferential access that their competitors enjoy, companies are more likely to base operations targeting Asia-Pacific markets in other countries in the region rather than the US.

As Asia-Pacific countries move forward with their trade agreements, they will increasingly set regional trade rules that serve their interests. Absent participation in a regional trade agreement, the US will find it difficult to shape Asia Pacific-wide trade rules on the range of issues - including services, high tech, and other knowledge-based and creative industries as well as intellectual property, standards, competition, and other issues - that are critical to future US economic growth, competitiveness, and jobs.
Finally, the competing Asia-Pacific trade strategies will have important geopolitical implications. For the US, having ceded regional influence to other countries by withdrawing from TPP, regaining it will be increasingly difficult. Other countries are stepping up to fill the leadership vacuum left by the US and may no longer be as willing to defer to it. Some may work with the US on specific issues on which they share common interests, but even on these issues, their willingness to cooperate will be undercut by their frustration over US unilateralism. Despite their misgivings, allies and partners will become more willing to work with US rivals, including China, given the reality of its growing influence and as a hedge against the unreliability and unpredictability of US trade and foreign policies.

Of course, the next US administration could seek to shift this trajectory. As it develops its trade and foreign policy policies, a new administration will evaluate the costs and benefits of the Trump Administration's America-First approach. It will take a fresh look at options for promoting US competitiveness and growth, and managing China's rise, as well as how best to ensure the benefits of trade and innovation are broadly shared. A new administration may put a renewed priority on reestablishing US leadership by rebuilding US alliances as well as on strengthening and modernizing the international institutions that underpin the rules-based global order. It may also seek to rejoin the TPP, a move that the other 11 members would likely welcome even if doing so required some renegotiation of the agreement. Doing so would be the quickest and most efficient way to reassert US economic and strategic interests in the Asia-Pacific region and promote US economic growth and prosperity.

Barbara Weisel (bweise|@rockcreekadvisors.com) is a Managing Director at Rock Creek Global Advisors, an international economic policy advisory firm based in Washington, DC. Previously, she served as Assistant U.S. Trade Representative for Southeast Asia and the Pacific, where she was the U.S. chief negotiator for the Trans-Pacific Partnership. She also served as negotiator of free trade agreements with Singapore, Australia, Thailand, and Malaysia, and led other trade and investment initiatives aimed at promoting U.S. interests in the Asia Pacific. 